\title{
Forest carbon management and carbon trading: A review of Canadian forest options for climate change mitigation
}

\author{
by Denise M. Golden ${ }^{1}$ M.A. (Peggy) Smith² and Stephen J. Colombo ${ }^{3}$
}

\begin{abstract}
Forests have significant potential to mitigate climate change. Canada has $30 \%$ of the world's boreal forests. The ratification of the Kyoto Protocol commoditized carbon (C) on an international scale. To achieve Canada's emission reduction targets and mitigate climate change, the potential of forest $\mathrm{C}$ offset projects and forest $\mathrm{C}$ trading is being evaluated. Carbon trading and forest $\mathrm{C}$ management have economic and policy implications and potential trade-offs in other forest management objectives. We discuss how forest $\mathrm{C}$ management and trading can contribute to global efforts for atmospheric greenhouse gas emissions reduction through either utilization and/or conservation strategies.
\end{abstract}

Key words: Canada, boreal forest, carbon management, carbon trading, climate change mitigation, forest carbon, forest conservation, forest management

\section{RÉSUMÉ}

Les forêts sont tout à fait capables d'atténuer les changements climatiques. Le Canada détient $30 \%$ des forêts boréales de la planète. La ratification du Protocole de Kyoto a transformé le carbone (C) en un produit de base se transigeant partout dans le monde. Le potentiel des projets de crédits de $\mathrm{C}$ forestier et déchange de $\mathrm{C}$ forestier destinés à permettre au Canada d’atteindre ses objectifs de réduction des émissions et d’atténuation des changements climatiques, fait lobjet d'une évaluation. Les échanges de $\mathrm{C}$ et la gestion du $\mathrm{C}$ forestier entrainent des répercussions économiques et politiques ainsi que des interactions potentielles avec d'autres objectifs d'aménagement forestier. Nous discutons comment la gestion du $\mathrm{C}$ forestier et ses échanges peuvent contribuer aux efforts globaux de réduction des gaz à effet de serre dans laatmosphère en fonction de stratégies d'utilisation ou de conservation.

Mots clés : Canada, forêt boréale, gestion du carbone, échange de carbone, atténuation des changements climatiques, carbone forestier, conservation forestière, aménagement forestier

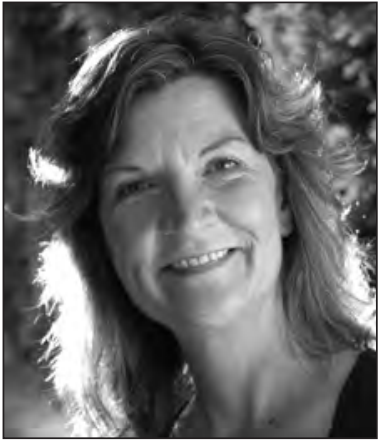

Denise M. Golden

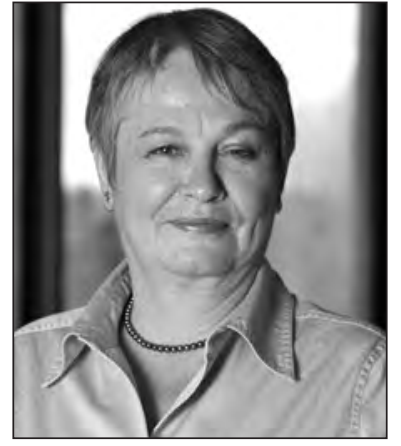

M.A. (Peggy) Smith

\section{Introduction}

Canada's forests, the practice of forestry in them, and the rules for forestry offsets and the accounting for forest carbon (C) under the Kyoto Protocol (KP) can have major consequences for meeting this country's commitment to mitigating climate change. The United Nations Framework Convention on Climate Change (UNFCCC) led to the development of the KP, both international mechanisms through which the global

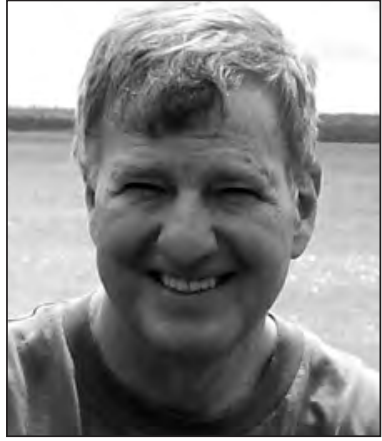

Stephen J. Colombo human causes of climate change are addressed. Canada ratified the KP in 2002, which entered into force internationally in 2005 , and committed itself to reducing emissions of six greenhouse gases (GHGs) to a combined $6 \%$ below its 1990 emissions levels (UNFCCC n.d.a). Canada (and the provinces within it) is a signatory to the Convention on Biological Diversity (CBD) and the UNCED Statement of Forest Principles, and is a member in the Montreal Process and other environmental and sustainable development policies relevant to forest management.

The intent of the KP is the avoidance of or reduction in atmospheric GHG emissions and the removal of GHGs by $\mathrm{C}$ sinks, including forests (UNFCCC n.d.b). Signatory countries agreed to submit annual GHG inventory reports to the UNFCCC on the six identified greenhouse gases-carbon dioxide $\left(\mathrm{CO}_{2}\right)$, methane $\left(\mathrm{CH}_{4}\right)$, nitrous oxide $\left(\mathrm{N}_{2} \mathrm{O}\right)$, hydro-

${ }^{1}$ PhD Student, Forest Sciences, Faculty of Graduate Studies, Lakehead University, 955 Oliver Road, Thunder Bay, Ontario P7B 5E1. E-mail: dmgolden@lakeheadu.ca

${ }^{2}$ Faculty of Natural Resources Management, Lakehead University, 955 Oliver Road, Thunder Bay, Ontario P7B 5E1.

${ }^{3}$ Ontario Forest Research Institute, Ministry of Natural Resources, 1235 Queen Street, Sault Ste. Marie, Ontario P6A 2E5. 
Table 1. Greenhouse gas emissions - megatonnes carbon dioxide equivalent for Canada, provinces, and territories in 1990 and 2008 (Environment Canada 2010)

\begin{tabular}{|c|c|c|c|c|}
\hline Carbon (kt $\mathrm{CO}_{2}$ eq) Jurisdiction & 1990 & 2008 & Difference 1990-2008 & $\%$ change 1990-2008 \\
\hline Canada & 592000 & 734000 & 142000 & 24.0 \\
\hline Alberta & 171000 & 244000 & 73000 & 42.7 \\
\hline British Columbia & 49300 & 65100 & 15800 & 32.0 \\
\hline Manitoba & 18600 & 21900 & 3300 & 17.7 \\
\hline New Brunswick & 15900 & 18000 & 2100 & 13.2 \\
\hline Newfoundland and Labrador & 9450 & 10100 & 650 & 6.9 \\
\hline Nova Scotia & 19000 & 20900 & 1900 & 10.0 \\
\hline Yukon, Northwest Territories, and Nunavut & 2051 & 2160 & 109 & 5.3 \\
\hline Ontario & 176000 & 190000 & 14000 & 8.0 \\
\hline Prince Edward Island & 1980 & 1970 & -10 & -0.5 \\
\hline Quebec & 82800 & 82000 & -800 & -1.0 \\
\hline Saskatchewan & 43400 & 75000 & 31600 & 72.8 \\
\hline
\end{tabular}

fluorocarbons (HFCs), perfluorocarbons (PFCs) and sulphur hexafluoride $\left(\mathrm{SF}_{6}\right)$ - generally derived from national energy statistics on the types and amounts of fuels combusted (Gupta et al. 2003). Emissions and removals due to land use change and optional (at present) emissions and removals due to forestry must also be reported; collectively, these are referred to as Land-Use, Land-Use Change and Forestry (LULUCF).

Canada's most recent National Inventory Report (NIR) by Environment Canada (EC 2010a) indicates that emissions have risen by $24 \%$ since 1990 , from $592000 \mathrm{kt} \mathrm{CO}_{2} \mathrm{eq}^{4}$ in 1990 to 734000 kt CO 2 eq in 2008 (Table 1). Reported emission sources and emissions growth vary widely by province and territory.

Canada-wide, the forestland component of the LULUCF sector was a net sink of $77.5 \mathrm{Mt}$ in 1990 (forest LULUCF removals greater than forest LULUCF emissions) but a source during 2002 to 2007 (emissions greater than removals). The recent trend of forests in the LULUCF sector being a source is due to natural disturbances, accentuated in recent years by the large-scale mountain pine beetle (Dendroctonus ponderosae Hopkins) outbreak in British Columbia and Alberta (Kurz et al. 2008), but also attributable to forest fires and wood removed from forests by harvest.

The inclusion of removals by the LULUCF sector recognizes that biological $\mathrm{C}$ sinks store $\mathrm{C}$ absorbed by plants and that human activity (i.e., forestry and agriculture practices) can affect the size of these sinks. However, while the KP recognises the importance of forests as $\mathrm{C}$ sinks (Binkley et al. 2002), the potential to claim forests as a climate change mitigation measure, instead of efforts for reductions at emission sources (e.g., coal-fired electricity generation), was so contentious that comprehensive forestry-based mitigation activities were capped and limited in the early stages of KP negotiations (Purdon 2009). In addition, default KP accounting rules treat $\mathrm{C}$ in harvested wood as being completely released into the atmosphere as $\mathrm{CO}_{2}$ at the time of harvest, even

$\overline{{ }^{4} \text { Different greenhouse gases have different warming potentials (the }}$ ability to trap and retain radiant heat) in the atmosphere; e.g., methane gas $\left(\mathrm{CH}_{4}\right)$ has 25 times more warming potential than carbon dioxide over a 100-year time horizon; therefore, to standardize reporting, GHGs are converted to their equivalent in $\mathrm{CO}_{2}$ warming potential and noted as $\mathrm{CO}_{2}$ eq. Source: http://www.ipcc.ch/publica tions_and_data/ar4/wg1/en/ch2s2-10-2.html though it is known that the $\mathrm{C}$ contained in wood products in use and in landfills is increasing (Chen et al. 2008, Kurz et al. 2008). The role of forests and forestry in climate mitigation is still a subject of debate in ongoing negotiations.

Under the KP, measures for reducing GHG emissions and GHG removal by sinks are to be achieved primarily through national actions (UNFCCC n.d.a). However, to assist countries in meeting commitments, the KP established three international market-based mechanisms: i) emissions trading (ET), also known as the carbon market ${ }^{5}$; ii) the Clean Development Mechanism (CDM), in which an industrialized country invests in a sustainable development project in a developing nation to generate $\mathrm{C}$ credits; and iii) Joint Implementation (JI) that allows industrialized and emerging industrialized countries that are signatory nations of the KP to generate C credits from GHG reduction projects (UNFCCC n.d.a.). These three mechanisms established $\mathrm{C}$ as a commodity on a global scale.

While viewed as a step forward in climate change mitigation, these market-based mechanisms were and are not without their critics. Criticisms of the KP and $\mathrm{C}$ markets have included: i) concern that market-based mechanisms may perpetuate the continuation of GHG emissions through the purchasing of $\mathrm{C}$ credits instead of actual emission reductions, i.e., fossil fuel emissions attributed to economic generation will continue to rise (Purdon 2009), ii) uncertainty over whether $\mathrm{C}$ trading achieves real, permanent, and measurable emission reductions (Galatowitsch 2009), and iii) the lack of a strong role for forest sinks in climate change mitigation policies (Binkley et al. 2002, Purdon 2009).

What are the considerations in forest $\mathrm{C}$ management, in relation to other forest management objectives such as timber, biofuel, biodiversity, and recreation? How can $\mathrm{C}$ markets and the price of $\mathrm{C}$ credits impact forest management decisions? Will utilization and/or conservation approaches in forest management achieve these objectives? Will there be potential trade-offs and what might those trade-offs be? The discussion in this paper does not provide definitive answers, but presents issues and challenges through a review of the literature on forest $\mathrm{C}$ management as a measure to mitigate climate change relevant to Canadian forests, and the evolution of forestry in

\footnotetext{
${ }^{5}$ Carbon emission reductions, deemed carbon credits, are treated as a commodity that can be bought and sold.
} 
the $\mathrm{C}$ marketplace that may impact forest management decision-making in Canada. The literature review was based on governmental, non-governmental and private sector websites, as well as a review of the academic, peer-reviewed literature searched through Web of Science since 2007.

\section{Canadian Forests and Carbon}

Forests have significant potential to act as C sinks (Binkley et al. 2002, Solomon et al. 2007) and management of forests for $\mathrm{C}$ is seen as an important tool in climate change mitigation (Hurteau et al. 2008, Nair et al. 2009). During the process of $\mathrm{C}$ sequestration, $\mathrm{CO}_{2}$ is taken-up from the atmosphere and transformed into "solid carbon" in forest vegetation (mainly in the trunks, branches, leaves, and roots of trees) with some of this $\mathrm{C}$ transferred to the forest floor and soil (Luckai and Larocque 2002). These different components of the forest containing $\mathrm{C}$ are called " $\mathrm{C}$ pools". The capacity and rate of $\mathrm{C}$ absorption, storage and release in the forest $\mathrm{C}$ cycle is related to the type of tree species and age class structure of the forest (Kurz and Apps 1993).

As a country with a vast forested area, Canada has a particular interest in the role of forests and forestry in climate change mitigation. Canada's forests contain globally significant C stocks. Canada has $30 \%$ of the world's boreal forest (NRCan 2009a) covering an area of 552 million hectares, and 307 million hectares of those are forest and other wooded lands (NRCan 2010). For C accounting purposes, only managed forests in Canada are considered, which totals 236 million hectares (NRCan 2009b). Annual gross GHG emissions from wildfire in Canada's managed forests between 1995 and 2000 have varied from 11 million tonnes in 2000 to 291 million tonnes $\mathrm{CO}_{2}$ eq in 1995 (net emissions in 1995 were 182 million tonnes) (NRCan 2009a). Net removals of $\mathrm{CO}_{2}$ eq in 1992 were 101 million tonnes (a year of relatively few fires), and between 1990 to 2007 Canadas managed forests acted as a net $C$ sink for 11 of those 18 years (NRCan 2009a). The fact forests sequester $\mathrm{C}$ and are an important component in the global $\mathrm{C}$ cycle makes them a potentially significant measure for climate change mitigation.

A forest $\mathrm{C}$ sequestration project, established in Saskatchewan in 2002, consists of both planting understocked stands and the creation of "Forest Carbon Reserves", where the harvesting of otherwise operable stands is prevented, with the expectation that avoiding harvesting creates a larger $\mathrm{C}$ stock than harvesting and converting the trees to wood products ${ }^{6}$ (Lemprière et al. 2002). In British Columbia, the Haida Gwaii "Climate Forest" project aims to restore coastal temperate rainforest to a C-rich old growth climax forest ecosystem. ${ }^{7}$ Under the Far North Act in Ontario, large areas of the boreal are to be set aside from development, in part to protect $\mathrm{C}$ stocks from activities that might cause the stocks to be reduced. There is also a "Fifty Million Tree" southern Ontario afforestation project with the planting goal to be achieved by 2020 (Parker et al. 2009).

\footnotetext{
${ }^{6}$ According to Price et al. (1997) and Ter-Mikaelian et al. (2008), managed Canadian forests can store more carbon than the same forests if unmanaged, depending on the frequency of stand-replacing disturbance.

${ }^{7}$ http://www.haidaclimate.com/content/view/37/27/.
}

The $\mathrm{C}$ market is viewed as a significant tool for reducing emissions worldwide (World Bank 2009); it is considered the most cost-effective measure to achieve emission reduction targets (King 2008, Galatowitsch 2009, Purdon 2009). In Canada, both federal and provincial governments are developing $\mathrm{C}$ trading systems and forestry offset protocols. Turning the Corner: An Action Plan to Reduce Greenhouse Gases and Air Pollution, provided the basis for setting out Canada's offset system under the Canadian Environmental Protection $\mathrm{Act}^{8}$ that has been on-going for a number of years (EC 2010a). A provincial example for forestry offsets is the launch by the Nature Conservancy of Canada of a large forest $\mathrm{C}$ project selling 700000 tonnes $\mathrm{CO}_{2}$ eq in $\mathrm{C}$ credits to the Pacific Carbon Trust in British Columbia (NCC 2011). These examples, although not an exhaustive list, demonstrate the use of forest $\mathrm{C}$ in Canada for climate change mitigation.

\section{The Carbon Marketplace and the Evolution of Forest Carbon Credits}

Carbon markets exist either because of governance mechanisms or as a voluntary measure in response to expected GHG emission regulations (Knox-Hayes 2009). The model for C trading is not new. A market-based system of $\mathrm{C}$ credits for emissions reduction is similar in concept to the allowances traded for emissions of acid rain-forming gases, which are controlled atmospheric pollutants traded in North American air sheds (EC 2005). Carbon credits, measured in units of metric tonnes of GHGs in $\mathrm{CO}_{2}$ eq are generated through either: i) project-based activities, also called offsets, which avoid, emit less, or remove GHGs than would have occurred had the project not been undertaken; or ii) unused emission allowances ${ }^{9}$ credited after an investment to reduce GHG emissions to achieve compliance (e.g., fuel switching or changes in industrial processes) (King 2008, Galatowitsch 2009).

Despite the global economic slow-down, worldwide C transactions in 2009 were valued at \$144B USD (CTW 2010, World Bank 2010) and \$120B USD in 2010 (BNEF 2011). Emission trading schemes, in both regulated and voluntary market systems (which emerged to meet $\mathrm{C}$ credit demands in the absence of regulated markets), "have been proposed, refined, and in a few cases put on ice at the national level in the U.S., Australia, Japan and Korea over the past year. At the provincial level, we have seen movement in the U.S., Canada and China" (Point Carbon 2011). Each trading scheme defines its own rules for trading and standards for allowable C credits (Purdon 2009). In this paper, a detailed review of trading schemes is not possible and only a discussion of forestry $\mathrm{C}$ credits is presented.

Forestry has always been the lesser cousin in the $\mathrm{C}$ trading market, suffering from an image problem (Fehnse 2008) because so many issues hindered the implementation of forest sequestration projects. During negotiations of the KP it was assumed that forestry $\mathrm{C}$ projects would reduce incentives to address the causes of climate change, especially the development and adoption of low-C energy solutions (Tavoni et al.

\footnotetext{
${ }^{8}$ Canadian Environmental Protection Act, 1999 (S.C.1999, c. 33)

${ }^{9}$ Emission allowances are granted by a regulatory body in which subscribing entities must not exceed their allocated (allowed) GHG emissions.
} 
2007), with some countries instead claiming large C sinks in their managed forests (Kurz et al. 2008). The development of forestry $\mathrm{C}$ trading was also hurt by indecision on the criteria and rules to manage and account for $\mathrm{C}$ in forest projects funded under the CDM and JI (Schmidt 2009). Definitions for afforestation and reforestation, with respect to implementing Article $3.3^{10}$ in the KP under LULUCF, and the subsequent $\mathrm{C}$ credits forestry offsets could generate, varied between country to country (i.e., national definitions of forests and forest cover) and from organization to organization (e.g., Intergovernmental Panel on Climate Change and the Food and Agriculture Organization; IPCC n.d.). In the absence of agreement on rules and definitions, forestry projects were excluded from the European Union Emissions Trading System (EU-ETS), considered the largest and most mature system in the offset marketplace (Purdon 2009), or penalized as "temporary" credits depressing demand for forestry offsets (World Bank 2009).

For forestry projects to be part of $\mathrm{C}$ trading, other issues also needed resolution including: i) additionality-would the project not have happened otherwise (Binkley et al. 2002, Purdon 2009); ii) permanence - the longevity and stability of the $\mathrm{C}$ pool sequestered, as over time forests can switch between being a C source to a C sink (Tavoni et al. 2007, Galik and Jackson 2009); iii) leakage-when emission reductions by an activity occurring in one area (i.e., bioenergy or conservation) inadvertently result in emissions in another location (i.e., harvesting or changes in forested land-use) (Tavoni et al. 2007, Galatowitsch 2009); and iv) ownership-a difference between rights to use the land (tenure) but not land ownership rights, thereby raising uncertainty about who has the right to sell C credits (Binkley et al.2002, RRI 2010). Along with these complicating factors, over six years of $\mathrm{C}$ trading has brought to light additional barriers to the development of forestry offset projects, including: i) difficulties in financing offset projects (Purdon 2009, World Bank 2009); ii) complicated and onerous project documentation requirements and registration processes, which add to transaction costs and create lengthy approval times (World Bank 2009); and iii) the need to incorporate sustainable development, social and community issues (Binkley et al. 2002, RRI 2010), and ecological soundness into projects (Galatowitsch 2009). van Kooten (2009) contends that terrestrial C sink activities, such as forestry offsets, require supporting institutions and mechanisms to be in place in advance of their inclusion in $\mathrm{C}$ trading systems.

It has been argued that the $\mathrm{C}$ marketplace itself hinders forestry projects. For small forest owners, a natural disturbance (e.g., fire and insect outbreaks) that reduces $\mathrm{C}$ stocks exposes forest owners to a liability for $\mathrm{C}$ sold but no longer held (Bigsby 2009, Galatowitsch 2009) and discourages C market participation. In addition, forest offset protocols that calculate a project's GHG removal from the project onset to a standing forest (as long as 100 years), without addressing permanence, ignores the risk of potential $\mathrm{C}$ losses caused by disturbances and may overestimate the project $\mathrm{C}$ value (Hurteau et al. 2009), thus reducing $C$ market confidence. More recent

\footnotetext{
${ }^{10}$ Article 3.3 refers to carbon fixed in "new" forests established on land not forested in 1990. Source: Watson et al. 2000.
}

forest offset project standards, such as the Verified Carbon Standard (VCS) require a non-permanence factor (a set-aside forested area as part of the project) to cover losses from fire or insects (VCS 2011). Bigsby (2009) suggests that an alternative to the current project-based offset system (permanent stores of $\mathrm{C}$ on a defined land base with a one-time payment) would be a system of "carbon-banking". This would be similar to capital investment mechanisms, in which those delivering the $\mathrm{C}$ sequestered (a deposit) receive annual payments and those using the $\mathrm{C}$ offset (a withdrawal) make annual payments. Despite the challenges, the use of forest sinks for offsets has risen. In $2007,18 \%$ of voluntary C market trades (7.6 million credits) were forestry offsets, and in 2008 the volume of forest offset trades increased, with many traders being first-time buyers of forest offsets (Neeff et al. 2009).

Along with growing interest in the voluntary market, forests as offsets are being addressed in regulatory and policy frameworks. This attention is seen in pending inclusion of forestry offsets in the EU-ETS, reduced restrictions within the $\mathrm{KP}$ for CDM forest projects and the consideration of wood products $\mathrm{C}$ as an allowable offset (UNFCCC n.d.b.). There are also increased forest conservation efforts such as the development of a mechanism to compensate for avoided deforestation in tropical countries-the United Nations Reduced Emissions from Deforestation and Forest Degradation programme (REDD 2010).

\section{Carbon Trading and Forestry Offsets in Canada}

In North America, the first mandatory GHG emissions reduction system came into effect in Alberta on July 1, 2007. Known as the Alberta-based Offset Credit System (Government of Alberta 2009), Alberta's scheme allows forestry offset projects with the restriction that the offset project be within Alberta (C3 2009). Forestry offset protocols are under development with regard to wetlands (conservation and/or restoration) and direct emission reductions (i.e., changes in wood processing technology), but avoided deforestation and improved forest management plans are not presently included (T. Maynes, personal communication. Climate Change Central, Edmonton, AB, July 9, 2010). Also in 2007, Manitoba joined Iowa, Illinois, Kansas, Michigan, Minnesota, and Wisconsin in the Midwestern Greenhouse Gas Reduction Accord (termed the "Accord"). An objective of the Accord is to promote consistency and integrity to increase market confidence in offset projects within the participating jurisdictions ${ }^{11}$. The Western Climate Initiative (WCI) is a collaboration between four Canadian provinces (British Columbia, Manitoba, Ontario, and Quebec) and seven U.S. states (Arizona, California, Montana, New Mexico, Oregon, Utah and Washington), with a goal to address climate change on a regional scale (WCI 2010a).

In July 2010, the Accord, the WCI, and a third initiative, the Regional Greenhouse Gas Initiative (RRGI) - a mandatory capped $\mathrm{CO}_{2}$ market-based scheme for the power sector in 10 states in the northeast and mid-Atlantic of the United States-joined in a cooperative effort to share experiences in the design and implementation of regional cap-and-trade

${ }^{11}$ http://www.midwesternaccord.org/ 
program (WCI 2010c). Afforestation, reforestation ${ }^{12}$, forest management, forest preservation and/or conservation, and wood products are being considered within this triumvirate of GHG emissions reduction networks (WCI 2010b).

In British Columbia, a form of cap-and-trade has been implemented for public sector organizations, which are mandated to reduce GHG emissions internally or purchase offsets from the Pacific Carbon Trust (PCT), a Crown corporation (Government of British Columbia 2008). The offset projects must take place in B.C. and can include afforestation, planting using select seed sources that have faster growth rates, increased timber volume and $\mathrm{C}$ content, forest fertilization, and resistance to insects and disease (BCMFR 2010). In 2009, Ontario passed Bill 185, a bill to promote a cap-and-trade GHG trading scheme (Legislative Assembly of Ontario n.d.a). Discussions about forestry protocol development are currently underway (Hall 2010), with offsets protocols expected to be in line with those identified by the WCI (OMOE 2011). Along with the development of carbon markets by some provinces, the Canadian federal government has set a federal offset system (Government of Canada 2009). The federal system is intended to encourage domestic reductions or removals and therefore limits CDM credits, which are international (EC 2009), to $10 \%$ of the total needed to achieve compliance $^{13}$. Moreover, CDM credits cannot be from forest $\mathrm{C}$ sink projects, because the Canadian government treats those credits as temporary ${ }^{14}$, in alignment with current $\mathrm{KP}$ rules $^{15}$ (EC 2009). Current forestry offset credits allowed under the Canadian federal system are: "i) afforestation/reforestation $^{16}$, creating a forest where none has existed since at

\footnotetext{
${ }^{12}$ Afforestation - Direct human-induced conversion of land that has not been forested for a period of at least 50 years to forested land through planting, seeding and/or the human-induced promotion of natural seed sources; Reforestation - Direct human-induced conversion of non-forested land to forested land through planting, seeding and/or the human-induced promotion of natural seed sources, on land that was previously forested but converted to non-forested land. For the first commitment period of the Kyoto Protocol, reforestation activities will be limited to reforestation occurring on those lands that did not contain forest on 31 December 1989. Source: http://www.ipcc.ch/pdf/glossary/ar4-wg3.pdf.

13“... credits from the Kyoto Protocol's Clean Development Mechanism could be used for compliance with the domestic regulations, limited to $10 \%$ of each firm's regulatory obligation". Source: http:// www.ec.gc.ca/doc/virage-corner/2008-03/541_eng.htm\#introduction (section 5.3)

14“'Temporary credits would represent only temporary storage of carbon, they would not be fully interchangeable with offset credits". Source: VII. Treatment of Biological Sink Projects - Temporary Credits \#114

15"All Clean Development Mechanism project credits will be accepted for compliance with the regulations, with the exception of credits for forest sink projects. Credits from forest sink projects are temporary under Kyoto Protocol rules. This means that they must be replaced periodically. Including credits from forestry projects would have added complexity to the domestic system without significantly reducing compliance costs for regulated industry". From: http:// www.ec.gc.ca/doc/virage-corner/2008-03/541_eng.htm\#introduction (section 5.3)

${ }^{16}$ The Canadian federal government defines Afforestation/Reforestation as: "planting trees on land that has not been a forest or that requires restocking". Source: http://www.ec.gc.ca/doc/virage-corner/ 2008-03/526_eng.htm\#AnnexB.
}

least 1990; ii) avoided or reduced deforestation: avoiding or reducing the permanent loss of a forest; or iii) forest management: managing activity, or changing the level of an existing activity, within a forest area that increases carbon sequestration" (e.g., fertilization, re-stocking) (EC 2010b).

In concert with offset credits as incentives to meet emission reductions, several Canadian provinces have introduced $\mathrm{C}$ taxes and fines for non-compliance under regulated emission regimes. Alberta levies a fine of $\$ 15 \mathrm{CAD}$ per tonne of $\mathrm{CO}_{2}$ on large emitters that fail to reduce their emissions intensity by $12 \%$. Quebec, in 2007, was the first North American jurisdiction to introduce a tax on $\mathrm{C}$, affecting fossil fuel distributors in the province. In 2008, British Columbia introduced a provincial $\mathrm{C}$ tax, with a plan to increase the tax to $\$ 30$ per tonne $\mathrm{CO}_{2}$ by 2012 (Government of British Columbia n.d.). A recent survey found preference was given to a combined $\mathrm{C}$ trading and $\mathrm{C}$ tax system as a measure to reduced GHG emissions (McAllister Opinion Research 2010). A C tax that allows emitters to purchase offsets in lieu of paying the tax could generate increased offset project development.

\section{Factors in Decision-Making for Forest Carbon Man- agement and Carbon Trading}

Along with regulating climate, forests provide a range of services and co-benefits to society. Forests cycle nutrients, provide flood control, supply timber, food and medicines, as well as social and cultural settings and recreational spaces (MEA 2003, Seppälä et al. 2009). Dilemmas can arise if forest management is modified to maximize $\mathrm{C}$ sequestration without preventing conflicts with other management objectives, ecological functions, and social or economic co-benefits (McCarney et al. 2008, Galatowitsch 2009).

Management efforts to increase forest $\mathrm{C}$ may affect biodiversity (Krcmar et al. 2005). Changes in biodiversity, if considered an unacceptable outcome, may lead to tough choices for climate change mitigation. Forest $\mathrm{C}$ management may entail compromises between ecological and social values. Sustainable forest management is intended to ensure that an acceptable balance is achieved among these choices. There are examples of forest management achieving both sustainability and increasing $\mathrm{C}$ storage, while allowing logging (GarciaGonzalo et al. 2007, Neilson et al. 2007, Chen et al. 2010). Issues in land ownership and cost-allocations-to-benefits faced by forest-based communities can affect implementation of C offset projects (Michaelowa 2007, Pinkerton et al. 2008). Moreover, decisions in offset projects have not always taken into consideration the knowledge of the local forest people, though people who live in forests have for centuries managed their forests considering environmental impacts and social and economic benefits (Hawken and Granoff 2010). Local governance, by people who live in and rely on the forest for food, fuel and other benefits such as flood control-not national or international authorities - may be more successful in delivering both $\mathrm{C}$ storage and co-benefits (RECOFTC 2009, RRI 2010). Recent discussions in Canada are exploring local decisions in making use of climate change modeling and risk assessments with climate change adaptation and sustainable forest management (see Klink et al. 2011).

In addition to fitting into current systems intended to satisfy multiple forest management and stakeholder objectives (e.g., biodiversity, sustainability), the contributions of forests 
to climate change mitigation must be based on an understanding of the size and mobility of forest $\mathrm{C}$ stocks. Forest $\mathrm{C}$ is present in live tree biomass, dead organic matter above ground and the forest floor, and forest soils (Kurz et al. 2008), and, after harvest, in wood products and eventually in landfills (Chen et al. 2010). Significant uncertainty exists about the size of forest $\mathrm{C}$ pools, including that in the above-ground boles of live trees. This reflects the fact that forestry in Canada has used empirical measurements of forests for more than half a century with the objective of determining the amount of merchantable volume in forest stands before they are harvested. Non-merchantable above-ground live tree biomass, below-ground live tree biomass, understory vegetation, downed deadwood, the forest floor and forest soil, while having been the subject of $\mathrm{C}$ research studies, are not normally assessed in Canada's extensive managed forests. In addition, changes in forest $\mathrm{C}$ after disturbance and the ability to increase $C$ sequestration through forest management are not well understood (Binkley et al. 2002, Gupta et al. 2003). This uncertainty has implications in decision-making for forest $\mathrm{C}$ management.

Uncertainty about forest $C$ sequestration potential is a major difficulty in determining the size of forestry offsets (Nair et. al 2009). Another source of error in C accounting is the default accounting procedure for harvested wood products set by the IPCC, which counts wood product emissions as fully emitted at the time of harvest, when in fact oxidation of $\mathrm{C}$ in wood products takes years to centuries (Chen et al. 2008). Trading programs and $C$ accounting standards can also influence management decisions. Galik and Jackson (2009) discuss the use of fertilization to increase forest $\mathrm{C}$ sequestration. Fertilization can increase forest biomass, but in allowable offset standards such as the Voluntary Carbon Standard, accounting must include total project emissions, including life-cycle emissions from synthetic fertilizer production and use, which lowers the net GHG benefit (Galik and Jackson 2009), potentially discouraging fertilization as a management strategy to increase C storage. Understanding the complexity of the impacts of forest management decisions is increasingly dependent on methods such as multi-objective optimization models (e.g., Maness and Farrell 2004).

A variety of forest modelling tools will be needed to assist in decision-making for forest $\mathrm{C}$ management and trading. One reason is the potentially long time frames of forest $\mathrm{C}$ projects, which will span what is expected to be a substantial change in climate. The northern boreal forest will probably be the first forest biome to experience large changes in climate (Fischlin et al. 2008, Bradshaw et al. 2009). Boreal forests are expected to shift poleward (Seppälä et al. 2009) and increase in growth through elevated temperatures and longer growing seasons (Thompson et al. 1998, Alam et al. 2008), provided other conditions, such as moisture and nutrients, are not limited (Johnston et al. 2006). Positive or negative changes in forest $\mathrm{C}$ sequestration depend on the nature of climate change within a specific region (Seppälä et al. 2009). As such, forestspecific information or factors influencing emissions or the accumulation of $\mathrm{C}$, such as eco-site climate, soil, tree density, species composition, and management practices, improve modelling accuracy (Chen et al. 2000, Nair et al. 2009). Understanding how climate change will alter forest $\mathrm{C}$ stocks will be important for medium- and long-term forest management decisions.

\section{Institutional Approaches for Climate Change Mitiga- tion with Forests: Utilization and Conservation}

In Canada, the debate around using forests to mitigate climate change has fallen into two major camps: i) those who recommend utilization through forest management to increase $\mathrm{C}$ storage (i.e., stored $\mathrm{C}$ in timber and wood products) and ii) those who argue for forest conservation, in which forest use is reduced or prohibited (i.e., protected areas) as the means to retain and increase $\mathrm{C}$ pools. Forest conservation relies entirely on the accumulation of $\mathrm{C}$ from natural forest ecosystem processes to sequester and store C. Utilization involves intentional activities to increase $\mathrm{C}$ uptake, storage or reduce $\mathrm{CO}_{2}$ emissions. These activities include such things as converting $\mathrm{C}$ from trees into a product for $\mathrm{C}$ storage (e.g., timber), which is replaced as harvested trees regrow, increasing forest growth or $\mathrm{C}$ uptake by management activities (e.g., tree planting and protection from natural disturbance), and displacing conventional energy production (e.g., using wood in place of more energy-intensive non-wood alternatives). Sectors of Canadian society involved in this debate include governments, Canada's Aboriginal people ${ }^{17}$, non-governmental and environmental organizations, and industry sectors and associations. Both approaches present challenges and benefits as mitigation measures, and forestry activities to mitigate global warming hinge on the signals directed by climate change policy and markets (Binkley et al. 2002).

In the debate on "what counts" as a forest $\mathrm{C}$ credit, or how $\mathrm{C}$ credits could be generated, it has been argued that a number of management and accounting practices that increase $\mathrm{C}$ stocks be considered. Examples include flexibility in harvest rotations, whether shortened to reduce losses to natural disturbances or increased to extend C storage in forests (Galik and Jackson 2009)," counting C stored in wood and other forest products (Chen et al. 2008), and crediting avoided emissions when wood products are used in place of materials with greater GHG emissions e.g., in construction materials (see Lawson 2008). Options for generating $\mathrm{C}$ credits to mitigate climate change have been shown to directly affect forest management decision-making.

Management for timber and $\mathrm{C}$ credits, when $\mathrm{C}$ prices are high, may lead to decreased timber harvesting (Backéus et al. 2006). When managing a forest for timber is less profitable than managing the same forest for conservation, "carbon investors will readily give away the potential financial returns from the timber investment to get low-price carbon credits" (Binkley et al. 2002). When timber harvesting and C credits are directly linked, the economics of forest $\mathrm{C}$ can change. Colombo et al. (2007) estimate that between 2000 and 2100, managed Ontario forests could provide wood products storing over 360 million tonnes of $\mathrm{C}$, equivalent to 15.9 million tonnes of $\mathrm{CO}_{2}$ annually, while forest $\mathrm{C}$ stocks would increase over 100 years by 69 million tonnes $\mathrm{C}$ (2.5 million tonnes $\mathrm{CO}_{2}$ eq annually). In this example, crediting $\mathrm{C}$ in forests but not in wood products would seem to promote reduced harvest to store more $\mathrm{C}$ in forests at the expense of creating wood products. This point was demonstrated by Backéus et al. (2006), who projected that an increased price for $\mathrm{C}$ would decrease harvest levels. Both Backéus et al. (2006) and Colombo et al.

\footnotetext{
17 "Aboriginal peoples" is defined by Canada's Constitution Act, 1982 to include "the Indian [status Indians under the Indian Act, commonly termed 'First Nations'], Inuit and Métis peoples of Canada".
} 
(2007) assumed current forest management and climate would prevail over the next century, while it appears inevitable that timber production and forest $C$ will be effected by climate change over this period.

Timber supply modelling under potential climate change scenarios shows that in the next 50 years North American timber production could decline as a result of climate induced die-back in forests (Seppälä et al. 2009), coupled with trends in decreased investment in timber production due to low market prices (Johnston et al. 2006). Decreased North American timber production could shift logging to other forest jurisdictions that may have less stringent controls on forestry practices, perhaps increasing global emissions from deforestation, and/or missed opportunities for increased forest $\mathrm{C}$ storage in managed forests. While conservation in place of logging also increases $\mathrm{C}$ stocks, forest $\mathrm{C}$ eventually reaches a maximum in protected areas and is subject to loss by largescale disturbance, whereas $\mathrm{C}$ in wood products is a relatively secure pool that continuously accumulates as forests re-grow and are harvested repeatedly.

Conservation also poses challenges, as reduced logging in one jurisdiction or removing large areas of forest from management may result in "leakage" (Sohngen 2009), by creating pressure to log forests elsewhere to meet timber or biofuel demands affecting $\mathrm{C}$ stocks in another jurisdiction and could have no net effect in global GHG reductions (NRCan 2007, Sohngen 2009). Moreover, if the supply of harvested timber for wood products is reduced, this could increase pressure for other, more energy-intensive building products using concrete and steel, or displace other wood products such as furniture (Lawson 2008, NRCan 2007, Suttie 2008). This could unintentionally increase overall GHG emissions since, as reported for the United Kingdom, substituting 1 cubic metre of concrete/red brick with timber saves 1 tonne of $\mathrm{CO}_{2}$, and maximising timber materials in a typical house construction can reduce $\mathrm{CO}_{2}$ emissions from 20 tonnes to 2.4 tonnes (Suttie 2008).

There is also a carbon-price link between using forests for C storage and forest fuel products (Backéus et al. 2006). The expansion of the biofuels industry, including fuels from wood stocks, is anticipated to have substantial impacts on global C storage (Negra et al. 2008). The success of using forest biomass for energy will depend on: i) the economic viability of the biofuel supply, with secure markets and dependable supply chains; ii) social acceptance through stakeholder engagement in bio energy development; and iii) demonstrated GHG emissions reductions, which includes net reduced $\mathrm{CO}_{2}$ absorption when changes in forest $\mathrm{C}$ are taken into account, the life cycle of emissions through forest operations and biofuel production, and the displacement of fossil fuel emissions (Elghalia et al. 2007, McKechnie et al. 2011).

There is also a correlation between the price of $\mathrm{C}$ and choice of biofuel feedstock. Backéus et al. (2006) showed that in Sweden, optimizing the net present value of forest operations discouraged harvest of forests for biofuel at higher $\mathrm{C}$ prices. They concluded that the greatest financial benefit came if $\mathrm{C}$ was left in the forest rather than by harvesting trees, collecting harvest residues, or thinning to obtain biomass for energy generation in place of oil. However, the conclusions made by Backéus et al. (2006) are highly dependent on assumptions concerning decomposition rates, risk of natural disturbance, forest longevity, growth rates if not disturbed, and the type of fossil fuel being replaced. Thus, it is not necessarily straightforward to extrapolate these results from Sweden to Canada, or from one part of Canada to another. It also has been shown the use of wood for bioenergy from forests that would otherwise not have been harvested, or from residues collected after harvest, increases net GHG emissions compared to coal when forest $\mathrm{C}$ impacts are factored into the GHG calculations (Manomet 2010, McKechnie et al. 2011). In addition, different forest biofuel feedstocks have different $\mathrm{C}$ emission profiles. Dead wood obtained after natural disturbances due to fire and insects in Canada could provide an increased volume of biofuel feedstock than woody residues obtained after clearcutting (Dymond et al. 2010). Although bio-energy generated from wood left after natural disturbances accelerates the release of GHG compared to on-site decay, the energy is renewable, can substitute for fossil fuels, and its mitigation potential should be judged on the combined changes in forest $\mathrm{C}$ and the life cycle emissions of each biofuel feedstock type (Dymond et al. 2010).

Another area in the discussion of $\mathrm{C}$ and forest management is afforestation-converting land that is not presently forested to forest land. Although this discussion is more prevalent in other countries, research has been conducted in Canada investigating afforestation with hybrid poplar. Dominy et al. (2010) report that, while there are not enough private lands available to fully offset Canada's emissions through $\mathrm{C}$ sequestration by tree planting in conjunction with biomass to replace fossil fuels, afforestation is an option in the suite of possible mitigation measures for addressing GHG emissions targets. At trading prices under $\$ 15 / \mathrm{tCO}_{2} \mathrm{eq}$, the rate of return on investment ( $8 \%$ to $12 \%)$ is relatively low, but at expected higher future C prices ( $\$ 16$ to $\$ 32 / \mathrm{tCO}_{2} \mathrm{eq}$ ), in addition to benefits from wood fibre and other environmental services, the economics of afforestation could dramatically change (Dominy et al. 2010).

The susceptibility of much of Canada's forests to largescale disturbance by fire or insect infestations strongly affects C stocks (Thompson et al. 1998, Hunt et al. 2010) and also needs to be considered in either utilization or conservation approaches to climate change mitigation. The recent transition of Canada's forests from a C sink to a C source is a result of the large-scale mountain pine beetle infestation in British Columbia (Kurz et al. 2008). In addition, GHG emissions from fires in Canada's managed forests have represented as much as $45 \%$ of Canada's total emissions in a given period (NRCan 2007). Accounting for changes in forest C is optional under the KP, and Canada opted not to include forests in the first KP commitment period (2008-2012) so emissions due to natural disturbance are also not included for accounting purposes. Forest management options for $\mathrm{C}$ sequestration in forests prone to stand-replacing disturbances causing potentially high $\mathrm{C}$ emissions requires a suite of tools to meet the challenges of climate change mitigation. Forest offset policies and protocols that do not provide credit for forest $\mathrm{C}$ management, while including emissions due to natural disturbances, or rules that restrict or limit allowable $\mathrm{C}$ credits (e.g., C stored in timber) are likely to discourage the use of forest management or interest in developing forest projects to mitigate climate change.

A critical component in implementing any policy or program for forest $\mathrm{C}$ management is to understand how economic incentives for $\mathrm{C}$ sequestration may affect the practice 
of sustainable forest management (McCarney et al. 2008). Key criteria for sustainable forest management in Canada include biological diversity and ecosystem productivity (CCFM 2006). Literature on managing the combined objectives of forest $\mathrm{C}$ management, timber and biodiversity is scarce (McCarney et al. 2008). According to McCarney et al. (2008), land-use specialization for timber and biodiversity, or timber and $\mathrm{C}$, may be more effective in achieving management objectives. However, the price of $\mathrm{C}$ credits has an influence. When $\mathrm{C}$ prices are low, multiple-use forest management (timber, biodiversity, and C) is the optimal use, but when $\mathrm{C}$ prices are high, land-use specialization increases (McCarney et al. 2008).

A land-use approach for both protecting biological diversity and mitigating climate change is to establish conservation areas, as protected regions or parks. In Canada, 27.6 million hectares have been set aside as national parks, and Ontario provincial parks cover an area of 7.9 million hectares (NRCan 2009a). There is also a commitment through the Canadian Biodiversity Strategy to extend Canada's network of protected areas (biologically and geographically) to include "natural regions" not yet represented (Johnston et al. 2006). In 2009, the Ontario government passed the Far North Act, An Act With Respect To Land Use Planning and Protection in the Far North (Legislative Assembly of Ontario n.d.b). The Far North Act legislated at least 225000 sq. km ( 50\% of the land area within the Act) for "protection" through a network of interconnected lands to provide habitat for species, and "fight the effects of global climate change" (OMNR 2011).

Primary forests ${ }^{18}$ are considered more resilient, with larger C stocks than forest plantations or modified natural forests (Thompson et al. 2009). However, primary forests in much of Canada's boreal forests are prone and adapted to fire disturbance (Thompson et al. 2009, Hunt et al. 2010) and future climate change is expected to reduce fire interval and increase fire size (Thompson et al. 1998). Thus, stand-replacing disturbances would potentially keep substantial forested areas in younger stands with lower C stocks (Hunt et al. 2010). Studies on Canada's forests have shown that in areas prone to high levels of natural disturbance, fire suppression in managed forests may result in higher $\mathrm{C}$ stocks than in primary forests (Kurz et al. 1997, Price et al. 1997). Although boreal forests have a broad genetic variability (i.e., the diversity of genetic traits within populations of species) and are highly adapted to and recover from regular disturbance (Thompson et al. 2009), ecosystems may behave unpredictably with changes in climatic conditions (Hannah 2010). The boreal forest of today may not be the forest on the landscape in 100 years.

According to Johnston et al. (2006), "an interpretation of existing policy and planning frameworks in Canada suggests that protected area management plans tend to support continued protection of current ecological communities, while the definition of ecological integrity, in contrast, supports protection of the processes that would facilitate ecosystem adaptation to climate change." Many terrestrial protected areas are in locations threatened by changing climatic condi-

\footnotetext{
18 Primary forests as defined by Thompson et al. (2009) are forest/ other wooded land of native species, where there are no clearly visible indications of human activities and the ecological processes are not significantly disturbed.
}

tions (Hannah 2010). Protected areas face multiple stresses and synergies between existing stresses, such as habitat loss, invasive species, and moisture changes, which have not been factored into ecological modelling for the potential impacts of climate change, and fewer adaptation options exist for protected areas than for actively and extensively managed lands and waters (Johnston et al. 2006). Conservation of forests as a climate change mitigation strategy may require reassessment of the set-aside land, and redefining "natural regions" (ecological integrity vs. biogeography) and terms for protection (managed or unmanaged). To use protected forests for their ability to store $\mathrm{C}$ with the changes brought about by climate change may well require management intervention, rather than simply excluding management.

Numerous options exist to manage and maximize forests for C sequestration (Galik and Jackson 2009). Some are designed for immediate or short-term benefit and others are intended for long-term $\mathrm{C}$ sequestration potential (Sohngen 2009). Sequestration through forestry does not create permanent stocks, but it can provide time to perhaps delay global warming impacts (Backéus et al. 2006). Uncertainties with climate change will require robust, adaptive forest management strategies at multiple scales with broad management tools in order to be responsive and adaptive to changing conditions, mitigate adverse impacts, or capitalize on opportunities (Baron et al. 2009, Innes et al. 2009).

\section{Conclusions}

Forests are essential both for sequestering $\mathrm{C}$ to mitigate global warming and for providing ecological services and human benefits. Climate change could result in significant changes in the ecosystem services provided by forests with impacts to both managed and unmanaged forests. International agreements to address climate change through market-based mechanisms and the protection of forest ecosystems are complicated by the diverse and complex nature of global forests and $\mathrm{C}$ dynamics. A silo perspective, or insufficient integration of decision-making within the forestry sector or across sectors, impedes the inclusion of forestry in climate change mitigation. Climate change is a global concern and national or regional policies affecting forest $\mathrm{C}$ that do not take into consideration impacts on global forest $C$ may not achieve the intended results for mitigation of climate change.

Six years of forest $\mathrm{C}$ trading have brought to light the inadequacies and inconsistencies in forestry offset protocols and trading system rules. The complexities and potential influence $\mathrm{C}$ markets have in forest management decisions has also come to light. Further challenges are hidden in the unintended effects and conflicts with forest management objectives when forestry climate change mitigation projects are implemented.

In our view, both utilization and conservation of Canadian forests can be appropriate climate change mitigation strategies, depending on the regional characteristics of forests, especially the incidence of stand-replacing disturbance. Utilization of forests to increase combined $\mathrm{C}$ stocks in forests and wood products cannot be ignored, especially as such utilization provides security against the large and direct GHG emissions caused by forest disturbances. A strategy for forest protection in Canada can also play a part in a national forest strategy for climate change mitigation. However, even with 
protection of forests, large-scale disturbances are a reality that can turn protected forests from $\mathrm{C}$ sinks into $\mathrm{C}$ sources for certain periods. Furthermore, long-term protection from all forms of disturbance will affect the biodiversity of disturbance-dependent Canadian forests.

Forest $\mathrm{C}$ sequestration and forestry offset activities may contribute to the goal of GHG emissions reduction and the objective of slowing the rate of global warming. However, forest $\mathrm{C}$ reductions cannot replace the need to reduce $\mathrm{GHG}$ emissions from the burning of fossil fuels. Uncertainties about the timing and extent of climate change will require robust, adaptive forest management strategies, incorporating a suite of options responsive to changing climate. With the threat posed by climate change to the sustainability of Canadian forests, uncertainties need to be removed about the stability of $\mathrm{C}$ markets and rules for forest $\mathrm{C}$ offset projects so that climate change mitigation efforts using forests can be pursued; all the tools in the tool box to mitigate climate change need to be employed.

\section{References}

Alam, A., A. Kilpelainen and S. Kellomaki. 2008. Impacts of thinning on growth, timber production and carbon stocks in Finland under changing climate. Scand. J. For. Res. 23: 501-512.

Backéus, S., P. Wikström and T. Lämås. 2006. Modeling carbon sequestration and timber production in a regional case study. Silva Fenn. 40: 615-629.

Baron, J.S., L. Gunderson, C.D. Allen, E. Fleishman, D. McKenzie, L.A. Meyerson, J. Oropeza and N. Stephenson. 2009. Options for national parks and reserves for adapting to climate change. Environ. Manage. 44: 1033-1042.

Bigsby, H. 2009. Carbon banking: Creating flexibility for forest owners. Forest Ecol. Manag. 257(1): 378-383.

Binkley, C.S., D. Brand, Z. Harkin, G. Bull, N.H. Ravindranath, M. Obersteiner, S. Nilsson, Y. Yamagata and M. Krott. 2002. Carbon sinks by the forest sector-options and needs for implementation. Forest Policy Econ. 4: 65-77.

[BNEF] Bloomberg New Energy Finance. 2011. Value of the Global Carbon Market Increases by $5 \%$ in 2010 but Volumes Decline. News Release January 6, 2011. Available at http://bnef.com/ Download/pressreleases/133/pdffile/.

Bradshaw, C.J.A., I.G. Warkentin and N. Sodhi. 2009. Urgent preservation of boreal carbon stocks and biodiversity. Trends Ecol. Evol. 24(10): 541-548.

[BCMFR] British Columbia Ministry of Forests and Range. 2010. British Columbia Forest Offset Guide. Government of British Columbia, Rep. 2010. Available at http://www.env.gov.bc.ca/cas/ legislation/.

[CCFM] Canadian Council of Forest Ministers. 2006. Criteria and Indicators of Sustainable Forest Management in Canada: Key Trends and Conditions 2005. Ottawa, ON. 11 p.

[CTW] Carbon Trade Watch. 2010. Carbon market "growth" is mainly fraudulent, World Bank report shows. News Article July, 20, 2010. Available at http://www.carbontradewatch.org/articles/carbon-market-growth-is-mainly-fraudulent-world-bank-report.html. Chen, W., J. Chen and J. Cihlar. 2000. An integrated terrestrial ecosystem carbon-budget model based on changes in disturbance, climate, and atmospheric chemistry. Ecol. Model.135: 55-79.

Chen, J., S. J. Colombo, M. T. Ter-Mikaelian and L. S. Heath. 2008. Future carbon storage in harvested wood products from Ontario's Crown forests. Can. J. Forest Res.38: 1947-1958.

Chen, J., S.J. Colombo, M.T. Ter-Mikaelian and L.S. Heath. 2010. Carbon budget of Ontario's managed forests and harvested wood products, 2001-2100. Forest Ecol. Manag. 259: 1385-1398.

[C3] Climate Change Central. 2009. Alberta's Carbon Offset Solu- tions [online]. Available at http://carbonoffsetsolutions.climatechangecentral.com/.

Colombo, S.J., J. Chen and M.T. Ter-Mikaelian. 2007. Carbon Storage in Ontario's Forest, 2000-2100. Research Note CCRN-06. 8 p. Dominy, S.W.J., R. Gilsenan, D.W. McKenney, D.J. Allen, T. Hatton, A. Koven, J. Cary, D. Yemshanov and D. Sidders. 2010. A retrospective and lessons learned from Natural Resources Canada's Forest 2020 afforestation initiative. Forest. Chron. 86: 339-347.

Dymond, C.C., B.D. Titus, G. Stinson and W.A. Kurz. 2010. Future quantities and spatial distribution of harvesting residue and dead wood from natural disturbances in Canada. Forest Ecol. Manag. 260: 181-192.

Elghalia, L., R. Clift, P. Sinclair, C. Panoutsou and A. Bauen. 2007. Developing a sustainability framework for the assessment of bioenergy systems. Energ. Policy 35: 6075-6083.

[EC] Environment Canada. 2005. Great Lakes Basin Airshed Management Framework Pilot Project: Canada-United States Air Quality Agreement. Ottawa, ON. Available at http://dsp-psd.pwgsc.gc.ca/ collection_2008/ec/En4-48-2005E.pdf.

2009. Turning the Corner: Regulatory Framework for Industrial Greenhouse Gas Emissions [online]. Available at http://www. ec.gc.ca/doc/virage-corner/2008-03/541_eng.htm\#introduction.

2010a. National Inventory Report - Part 3 1990-2008

Greenhouse Gas Sources and Sinks in Canada. Environment Canada, Government of Canada, Ottawa, ON. 221 p.

2010b. Environment Canada (EC). 2010. Overview of the Offset System Guide [online]. Available at http://www.ec.gc.ca/ creditscompensatoires-offsets/default.asp?lang=En\&n=92CA76F4 -1 \&offset $=1$ \&toc $=$ show.

Fehnse, J. 2008. Carbon offset initiatives - international carbon markets. In G. Hemery and S. Greig (comps.). Carbon Lean UK: a role for our trees, wood and forest? ICF National Conference Proceedings, Pollock Halls, University of Edinburgh, Edinburgh, 23-24 April, 2008. pp. 14-15. Institute of Chartered Foresters, Edinburgh. Fischlin, A., G.F. Midgley, J.T. Price, R. Leemans, B. Gopal, C. Turley, M.D.A. Rounsevell, O.P. Dube, J. Tarazona and A.A. Velichko. 2008. Ecosystems, their properties, goods, and services. In M.L. Parry, O.F. Canziani, J.P. Palutikof, P.J. van der Linden and C.E. Hanson (eds.). Climate Change 2007: Impacts, Adaptation and Vulnerability. Contribution of Working Group II to the Fourth Assessment Report of the Intergovernmental Panel on Climate Change. pp. 211-272. Cambridge University Press, Cambridge, UK.

Galatowitsch, S.M. 2009. Carbon offsets as ecological restorations. Restor. Ecol. 17: 563-570.

Galik, C.S. and R.B. Jackson. 2009. Risks to forest carbon offset projects in a changing climate. Forest Ecol. Manag. 257: 2209-2216. Garcia-Gonzalo, J. H. Peltola, A.Z. Gerendiain and S. Kellomaki. 2007. Impacts of forest landscape structure and management on timber production and carbon stocks in the boreal forest ecosystem under changing climate. Forest Ecol. Manag. 241: 243-257.

Government of Alberta. 2009. Environment Greenhouse Gas Reduction Program [online]. Available at http://environment. alberta.ca/631.html.

Government of British Columbia. 2008. Ministry of Environment. Carbon Neutral Government Regulation. B.C. Reg. 392/2008.

Government of British Columbia. n.d. Ministry of Environment. Climate Change Secretariat. Legislation and Regulations [online]. Available at http://www.env.gov.bc.ca/cas/legislation/index.html\#CTA. Government of Canada. 2009. Canada's Action Plan on Climate Change [online]. Available at http://www.climatechange.gc.ca..

Gupta, J., X. Olsthoorn and E. Rotenberg. 2003. The role of scientific uncertainty in compliance with the Kyoto Protocol to the Climate Change Convention. Environ. Sci. Policy 6: 475-486.

Hall, J.P. 2010. Carbon Offsets and Carbon Credits. Eastern Ontario Model Forest. 3 p. Available at http://www.eomf.on.ca/index.php? option=com_k2\&view=item\&id=295: carbon-offsets\&Itemid $=403$ \&lang=en 
Hannah, L. 2010. A global conservation system for climate-change adaptation. Conserv. Biol. 24: 70-77.

Hawken, I.A. and I.M.E. Granoff. 2010. Reimagining park ideals: Toward effective human-inhabited protected areas. J. Sustain. Forestry 29: 122-134.

Hunt, S.L., A.M. Gordon and D.M. Morris. 2010. Carbon Stocks in Managed Conifer Forests in Northern Ontario, Canada. Silva Fenn. 44: 563-582.

Hurteau, M.D., B.A. Hungate and G.W Koch. 2009. Accounting for risk in valuing forest carbon offsets. Carbon Balance Manage. 4: 1-4. Hurteau, M.D., G.W. Koch and B.A. Hungate. 2008. Carbon protection and fire risk reduction: toward a full accounting of forest carbon offsets. Front. Ecol. Environ. 6: 493-498. (abstract).

Innes, J. et al. 2009. Management for Adaptation. In R. Seppälä, A. Buck and P. Katila (eds.). Adaptation of Forests and People to Climate Change. A Global Assessment Report. pp. 135-169. International Union of Forest Research Organizations (IUFRO), Helsinki. 224 p.

[IPCC] Intergovernmental Panel on Climate Change. n.d. Land Use, Land-Use Change and Forestry. 3.2.1. Definitional Scenarios Definitional scenarios related to Article 3.3 and defining forest, afforestation, reforestation, and deforestation [online]. Available at http://www.ipcc.ch/ipccreports/sres/land_use/124.htm.

Johnston, M., T. Williamson, D. Price, D. Spittlehouse, A. Wellstead, P. Gray, D. Scott, S. Askew and S. Webber. 2006. Adapting Forest Management to the Impacts of Climate Change in Canada. A BIOCAP Research Integration Program Synthesis Paper. Available at http://www.biocap.ca/rif/report/Johnston_M.pdf.

King, M.R. 2008. An overview of carbon markets and emissions trading: Lessons for Canada. Bank of Canada, Rep. Discussion Paper 2008-1. Ottawa, ON.14 p.

Klenk, N.K., B.W. Adams, G.Q. Bull, J.L. Innes, S.J. Cohen and B.C. Larson. 2011. Climate change adaptation and sustainable forest management: A proposed reflexive research agenda. Forest. Chron. 87: 351-357.

Knox-Hayes, J. 2009. The developing carbon financial service industry: expertise, adaptation and complementarily in London and New York. J. Econ. Geogr. 9: 749-777.

Krcmar, E., G.C. van Kooten, and I. Vertinsky. 2005. Managing forest and marginal agricultural land for multiple tradeoffs: compromising on economic, carbon and structural diversity objectives. Ecol. Model. 185: 451-468.

Kurz, W.A. and M.J. Apps. 1993. Contributions of northern forests to the global C cycle: Canada a case study. Water Air Soil Poll. 70: 163-176.

Kurz, W.A., S. J. Beukema and M. J. Apps. 1997. Carbon budget implications of the transition from natural to managed disturbance regimes in forest landscapes. Mitig. Adapt. Strateg. Glob. Change 2: 405-421.

Kurz, W.A., G. Stinson, G.J. Rampley, C.C. Dymond, and E.T. Neilson. 2008. Risk of natural disturbances makes future contribution of Canada's forest to the global carbon cycle highly uncertain. P. Natl. Acad. Sci. USA 105: 1551-1555.

Lawson, G. 2008. Life cycle analysis - embodied energy and energy accounting. In G. Hemery and S. Greig (comps.). Carbon Lean UK: a role for our trees, wood and forest? ICF National Conference Proceedings, Pollock Halls, University of Edinburgh, Edinburgh, 23-24 April, 2008. pp. 8-9. Institute of Chartered Foresters, Edinburgh.

Legislative Assembly of Ontario. n.d.a. Bill 185, Environmental Protection Amendment Act (Greenhouse Gas Emissions Trading), 2009. Available at http://www.ontla.on.ca/web/bills/bills_detail.do? locale $=$ en $\&$ BillID $=2195 \&$ detailPage $=$ bills_detail_status\&Intranet $=$ - n.d.b. Bill 191, Far North Act. Available at http:// www.ontla.on.ca/web/bills/bills_detail.do?locale=en \&Intranet= \&BilliD $=2205$.

Lemprière, T.C., M. Johnston, A. Willcocks, B. Bogdanski, D. Bisson, M. Apps and O. Bussler. 2002. Saskatchewan forest carbon sequestration project. Forest. Chron. 78: 843-849.
Luckai, N. and G.R. Larocque. 2002. Challenges in the application of exiting process-based models to predict the effect of climate change on C pools in forest ecosystems. Climatic Change 55: 39-60. Maness, T. and R. Farrell. 2004. A multi-objective scenario evaluation model for sustainable forest management using criteria and indicators. Canadian Journal of Forest Research 34: 2004 -2017.

[Manomet] Manomet Center for Conservation Sciences. 2010. Massachusetts Biomass Sustainability and Carbon Policy Study: Report to the Commonwealth of Massachusetts Department of Energy Resources. T. Walker. (ed.). Contributors: P. Cardellichio, A. Colnes, J. Gunn, B. Kittler, R. Perschel, C. Recchia, D. Saah, D and T. Walker. Natural Capital Initiative Report NCI-2010-03. Brunswick, ME. 182 p.

McAllister Opinion Research. 2010. Global Thought Leader Survey on Sustainability - Climate Change, Sustainable Energy, Green Economics and Oil Sands. Commissioned by the Pembina Institute. Available at http://pubs.pembina.org/reports/thought-leader-survey-2010-pembina-summary.pdf.

McCarney, G.R., G.W. Armstrong and W.L. Adamowicz. 2008. Joint production of timber, carbon and wildlife habitat in the Canadian boreal plains. Can. J. For. Res. 38: 1478-1493.

McKechnie, J., S.J. Colombo, J. Chen, W. Mabee and H.L. MacLean. 2011. Forest bioenergy or forest carbon? Assessing tradeoffs in greenhouse gas mitigation with wood-based fuels. Environ. Sci. Technol. 45: 789-795.

Michaelowa, A. 2007. Unilateral CDM: Can developing countries finance generation of greenhouse gas emission credits on their own? Int. Environ. Agreem-P. 7: 17-34.

[MEA] Millennium Ecosystem Assessment. 2003. Ecosystems and Human Well-being: A Framework for Assessment. Chapter 2. Island Press, Washington, DC. Available at http://pdf.wri.org/ecosystems_ human_wellbeing.pdf.

Nair, R., B. Mohan Kumar and V. Nair. 2009. Agroforestry as a strategy for carbon sequestration. J. Plant Nutr. Soil Sc. 172:10-23.

[NRCan] Natural Resources Canada. 2007. Does Harvesting in Canada's Forests Contribute to Climate Change? Canadian Forest Service - Science Policy Notes. Ottawa. Available at http://www.sfmcanada.org/CMFiles/PublicationLibrary/CFS_DoesHarvesting InCanadasForestsContributeToClimateChange_English1OVA -25012010-8256.pdf.

2009a. The State of Canada's Forests. Annual Report 2009. 2009. Natural Resources Canada, Canadian Forest Service, Headquarters, Ottawa. 55 p. Available at http://cfs.nrcan.gc.ca/publications/?id=30071.

2009b. Forest Carbon Accounting [online]. Available at http://carbon.cfs.nrcan.gc.ca/FAQ_e.html\#2a.

2010. Boreal forest: Key facts [online]. Available at http://canadaforests.nrcan.gc.ca/article/borealforest.

[NCC] Nature Conservancy of Canada. 2011. Using the Trees to Save the Forest Press Release Vancouver, June 8, 2011 [online]. Available at http://www.newswire.ca/en/releases/archive/June2011/ 08/c3995.html

Neeff, T., L. Eichler, I. Deecke and J. Fehse. 2009. The Forest Carbon Offsetting Report 2009. EcoSecurities Report. Available at http://www.ecosecurites.com.

Negra, C., C.C. Sweedo, K. Cavender-Bares and R. O’Malley. 2008. Indicators of carbon storage in US ecosystems: Baseline for terrestrial carbon. J. Environ. Qual. 37: 1376-1382.

Neilson, E.T., D.A. MacLean, F.R. Meng and P.A. Arp. 2007. Spatial distribution of carbon in natural and managed stands in an industrial forest in New Brunswick, Canada. Forest Ecol. Manag. 253: $148-160$

[OMOE] Ontario Ministry of Environment. 2011. Participating in Cap and Trade [online]. Available at http://www.ene.gov.on.ca/environment/en/category/climate_change/STDPROD_078899.html.

[OMNR] Ontario Ministry Natural Resources. 2010. Forecasting Carbon Storage and Carbon Offsets for Southern Ontario Afforesta- 
tion Projects: The 50 Million Trees Planting Project [online]. Available at http://www.mnr.gov.on.ca/en/Business/ClimateChange/Publication/284399.html.

2011. Far North Ontario [online]. Available at http://www. mnr.gov.on.ca/en/Business/FarNorth/.

Parker, W.C., G. Nielsen, J. Gleeson and R. Keen. 2009. Forecasting Carbon Storage and Carbon Offsets for Southern Ontario Afforestation Projects: The 50 Million Tree Planting Program. Climate Change Research Note Number 10. Applied Research Branch, Ontario Ministry of Natural Resources, 8 p. Available at http://www.mnr.gov.on.ca/stdprodconsume/groups/lr/@mnr/ @climatechange/documents/document/276933.pdf

Price, D.T., D.H. Halliwell, M.J. Apps, W.A. Kurz and S.R. Curry. 1997. Comprehensive assessment of carbon stocks and fluxes in a Boreal Cordilleran forest management unit. Can. J. For. Res. 27: 2005.2016.

Pinkerton, E., R. Heaslip, J.J. Silver and K. Furman. 2008. Finding "Space" for co-management of forests within the Neoliberal paradigm: Rights, strategies, and tools for asserting a local agenda. Hum. Ecol. 36: 343-355.

Point Carbon. 2011. Carbon 2011 - Point Carbon's 7th annual conference, Carbon Market Insights 2011 in Amsterdam, 1-3 March 2011. Thomson Reuters Point Carbon. 48 p. Available at http://www. pointcarbon.com/polopoly_fs/1.1545244!Carbon\%202011_web.pdf. Purdon, M. 2009. Bio-carbon Overview. In Bio-carbon in Africa: Harnessing Carbon Finance to Promote Sustainable Forestry, Agro-Forestry and Bio-Energy. pp. 2-25. United Nations Development Programme, New York. 304 p.

RECOFTC. 2009. First Regional Forum for People and Forests: Carbon Financing and Community Forestry in Key Forum Conclusions, August 18-20, Hanoi, Vietnam. The Centre for People and Forests, Bangkok, Thailand 4 p. Available at http://www.recoftc.org/ site/uploads/content/pdf/Call_Action_31.pdf.

[REDD] Reducing Emissions from Deforestation and Degradation. 2010. A Casebook of On-the-Ground Experience. The Nature Conservancy, Conservation International and Wildlife Conservation Society, Arlington, Virginia. 72 p.

[RRI] Rights and Resources Initiative. 2010. The End of the Hinterland: Forests, Conflict and Climate Change 2009-2010. Rights and Resources Group, Washington, D.C. 28 p. Available at http://www.rightsandresources.org/documents/files/doc_1400.pdf. Schmidt, C.W. 2009. Carbon offsets: Growing pains in a growing market. Environ. Health Persp. 117(2): 62-68.

Seppälä, R., A. Buck and P. Katila. 2009. Executive Summary. In Adaptation of Forests and People to Climate Change. A Global Assessment Report. pp. 9-14. International Union of Forest Research Organizations (IUFRO), World Series Vol. 22. Helsinki. $224 \mathrm{p}$.

Sohngen, B. 2009. An Analysis of Forestry Carbon Sequestration as a Response to Climate Change. Copenhagen Consensus on Climate. Denmark. 29 p. Available at http://fixtheclimate.com/component1/the-solutions-new-research/forestry/.

Solomon, S., D. Qin, M. Manning, Z. Chen, M. Marquis, K.B. Averyt, M. Tignor and H.L. Miller (eds.). 2007. Climate Change 2007: The Physical Science Basis. Contribution of Working Group I to the Fourth Assessment Report of the Intergovernmental Panel on Climate Change. Cambridge University Press, Cambridge, UK and New York. 996 p.
Suttie, E. 2008. Wood for material substitution - construction with wood. In G. Hemery and S. Greig (comps.). Carbon Lean UK: a role for our trees, wood and forest? ICF National Conference Proceedings, Pollock Halls, University of Edinburgh, Edinburgh, 23-24 April, 2008. pp. 21-22. Institute of Chartered Foresters, Edinburgh. Tavoni, M., B. Sohngen and V. Bosetti. 2007. Forestry and the carbon market response to stabilize climate. Energ. Policy 35: 5346-5353.

Ter-Mikaelian, M.T., S.J. Colombo and J. Chen. 2008. Fact and fantasy about forest carbon. Forest. Chron. 84: 166-171.

Thompson, I., M.D. Flannigan, B.M. Wotton and R. Suffling. 1998. The effects of climate change on landscape diversity: An example in Ontario Forests. Environ. Monit. Assess. 49: 213-233.

Thompson, I., B. Mackey, S. McNulty, and A. Mosseler. 2009. Forest Resilience, Biodiversity, and Climate Change. A synthesis of the biodiversity/resilience/stability relationship in forest ecosystems. Secretariat of the Convention on Biological Diversity, Montreal. Technical Series No. 43. 67 p. Available at http://www.cbd.int/doc/ publications/cbd-ts-43-en.pdf.

[UNFCCC] United Nations Framework Convention on Climate Change. n.d.a. Kyoto Protocol: The Kyoto Mechanisms [online]. Available at http://unfccc.int/kyoto_protocol/items/2830.php.

n.d.b. LULUCF under the Kyoto Protocol [online]. Available at http://unfccc.int/methods_and_science/lulucf/items/4129.php. van Kooten, G.C. 2009. Biological carbon sequestration and carbon trading re-visited. Climatic Change 95(3-4): 449-463.

[VCS] Verified Carbon Standard. 2011. Agriculture, Forestry and Other Land Use (AFOLU) Requirements. VCS Version 3. Available at http://www.carbonpositive.net/viewarticle.aspx?articleID=1828.

Watson, R.T., I.R. Noble, B. Bolin, N.H. Ravindranath, D.J. Verardo and D.J. Dokken (eds.). 2000. Land Use, Land Use Change and Forestry. A Special Report of the IPCC, Cambridge University Press, Cambridge, UK. Available at http://www.ipcc.ch/ipccreports/ sres/land_use/index.php?idp $=0$.

[WCI] Western Climate Initiative. 2010a. Three Regions Release Joint Offset Quality White Paper [online]. Available at http://www. westernclimateinitiative.org/news-and-updates/110-three-regionsrelease-joint-offset-quality-white-paper.

2010b. Design Recommendations for the WCI Regional Cap-and-Trade Program [online]. Available at http://www.westernclimateinitiative.org/the-wci-cap-and-trade-program/design-recommendations.

2010c. Western Climate Initiative, Offset Definition (Task 1.1) and Eligibility Criteria Task 1.2) [online]. Available at http://www.westernclimateinitiative.org/document-archives/Offsets-Committee-Documents/Offset-Definition-(Task-1.1)-and-Eligibility-Criteria-(Task-1.2)-White-Paper/.

World Bank. 2009. 10 Years of Experience in Carbon Finance: Insight from working with carbon markets for development and global greenhouse gas mitigation. The World Bank Washington, D.C. 20 p.

World Bank. 2010. Carbon Finance for Sustainable Development 2010 Annual Report. World Bank, Washington, DC. Available at http://siteresources.worldbank.org/INTCARBONFINANCE/Resou rces/64897_World_Bank_web_lower_Res.pdf. 